Corvinus University of Budapest, Budapest, Hungría

Recibido: 3 de diciembre de 2015

Concepto de evaluación: 29 de junio de 2016

Aprobado: 20 de octubre de 2016

Artículo de investigación (C) 2017 Universidad Católica de Colombia. Facultad de Ciencias Económicas y Administrativas. Todos los derechos reservados

* PhD of Economics, Associate Professor at Corvinus University of Budapest, Hungary. Research fellow at Századvég Economic Research Co., and recipient of the Bolyai Scholarship of the Hungarian Academy of Science and the KAAD

Osteuropaprogramm. Address: Fovám Tér 8. (C.161) 1993, Budapest, Hungary. E-mail: gabor.kutasi@uni-corvinus.hu

\section{Unsustainable Public Debt in a European Fiscal Union?}

\section{ABSTRACT}

Some EU members faced years of crisis in the first half of the 2010s with an excessive initial public debt, but several others had broad room for fiscal stimulus. However, the prolonged duration of the European economic depression expended public budgets, while exhausting stimulus policies and sovereign solvency. Meanwhile, one of the ways out of depression is a proposed centralization of the EU through fiscal union. Are the eurozone countries ready to participate in a risk pool in public finances? The study seeks to answer this question. The article presents the hypothesis that the sustainability of public finances deteriorated during the global and euro crisis in the majority of the eurozone member countries and in the EU, and this phenomenon is discouraging the core countries from seeking the fiscal union. The analysis uses the Blanchard indicators of fiscal sustainability and the sovereign risk rating of the EURO-18 and EU-28 countries. The analysis presents as results a theoretical summary of fiscal sustainability, the development of fiscal sustainability in the EU member states, indicators of convergence or divergence of fiscal sustainability in the Community, and conclusions based on the indicators of the likelihood of a fiscal union.

Keyworlds: fiscal sustainability, euro zone.

JEL: E62, F34, H62

\section{¿Deuda pública insostenible en una unión fiscal europea?}

\section{RESUMEN}

Algunos miembros de la UE enfrentaron años de crisis en la primera mitad de la década de 2010 con una excesiva deuda pública inicial, pero varios otros tenían amplio margen para estímulos fiscales. Sin embargo, la prolongada duración de la depresión económica europea agotó los presupuestos públicos, debilitando las políticas de estímulo y la solvencia soberana. Mientras tanto, una de las formas de salir de la depresión es una centralización propuesta de la UE mediante una unión fiscal. ¿Están los países de la eurozona dispuestos a participar en un fondo de riesgo en las finanzas públicas? El estudio busca responder a esta pregunta. El artículo presenta la hipótesis de que la sostenibilidad de las finanzas públicas se deterioró durante la crisis global y la crisis del euro en 
la mayoría de los países miembros de la eurozona y en la UE, lo cual desalienta a los países centrales de buscar la unión fiscal. El análisis utiliza los indicadores de sostenibilidad fiscal de Blanchard y la calificación de riesgo soberano de los países de EURO-18 y UE-28. El análisis presenta como resultados un resumen teórico de la sostenibilidad fiscal, el desarrollo de la sostenibilidad fiscal en los Estados miembros de la UE, los indicadores de convergencia o divergencia de sostenibilidad fiscal en la Comunidad y conclusiones basadas en los indicadores de la probabilidad de una unión fiscal.

Palabras clave: sostenibilidad fiscal, eurozona.

\section{Dívida pública insustentável numa união fiscal europeia?}

\section{RESUMO}

Alguns membros da União Europeia (EU) enfrentaram anos de crise na primeira metade da década de 2010 com uma excessiva dívida pública inicial, mas vários outros tinham ampla margem para incentivos fiscais. Contudo, a prolongada duração da depressão econômica europeia esgotou o orçamentos público, o que debilitou as políticas de incentivo e solvência soberana. Enquanto isso, uma das formas de sair da depressão é uma centralização proposta pela UE mediante uma união fiscal. Os países da Zona do Euro estão dispostos a participar de um fundo de risco nas finanças públicas? Este estudo pretende responder a essa pergunta. $\mathrm{O}$ artigo apresenta a hipótese de que a sustentabilidade das finanças públicas se deteriorou durante a crise global e a crise do euro na maioria dos países-membros da Zona do Euro e na UE, o que desencorajou os países centrais a buscarem a união fiscal. A análise utiliza os indicadores de sustentabilidade fiscal de Blanchard e a qualificação de risco soberano dos países da EURO-18 e UE-28. Além disso, apresenta como resultados um resumo teórico da sustentabilidade fiscal, do desenvolvimento da sustentabilidade fiscal nos Estados-membros da UE, dos indicadores de convergência ou divergência de sustentabilidade fiscal na comunidade e conclusões baseadas nos indicadores da probabilidade de uma união fiscal.

Palavras-chave: sustentabilidade fiscal, Zona do Euro. 


\section{INTRODUCTION}

In 2009, several EU members faced years of crisis with an excessive initial public debt, but some others had broad room for fiscal stimulus. However, the prolonged duration of the European economic depression expended public budgets, while exhausting stimulus policies and sovereign solvency. Meanwhile, one of the ways out of depression is a proposed centralization of the EU through fiscal union.

As Benczes (2014: 66) explained regarding the fiscal union, this is not a new plan, as the idea or necessity of a fiscal union accompanied by monetary integration already appeared in the MacDougall Report (1977) as well as in the Delors Report (1989). Fuest and Peichel (2012) identified several elements of the fiscal union. ${ }^{1}$ The present study is related to the risk pool that originated in joint guarantees for each other's public debt or even each other's external debt through fiscal transfers and equalization. Are the eurozone countries or the whole EU finally ready to participate in a risk pool in public finances? The study seeks to answer this question.

There is a well-developed and broad literature about budget constraints, default risks, fiscal vulnerability and debt sustainability indexes (Mankiw, 1997; Barro, 2008; Fatás et al., 2003; Buiter \& Grafe, 2002; Zee, 1988; Tobin \& Buiter, 1976; Barnhill \& Kopits, 2003; Trehan \& Walsh, 1988; Blanchard, 1990; etc.) The present analysis is based on this state-of-the-art. The analysis uses the Blanchard indicators of fiscal sustainability and the sovereign risk rating of the EURO-19 and EU-28 countries. The applied fiscal sustainability indicators are the primary gap indicator and the tax gap indicator proposed by Blanchard (1990). After calculating and collecting these values, standard deviation and average risk indicators will be used to examine discouragement. The analysis presents as results a theoretical summary of fiscal sustainability, the development of fiscal sustainability of EU member

1 Rules, crisis mechanism, joint guarantee for public debt, fiscal transfers, federal budget, and taxes. states, indicators of convergence or divergence of fiscal sustainability in the Community, and conclusions based on the indicators of the likelihood of a fiscal union.

The paper presents the hypothesis that the sustainability of public finances deteriorated during the global and euro crisis in the majority of eurozone member countries and in the EU, and this phenomenon is discouraging the core countries from a fiscal union.

\section{THEORY OF FISCAL SUSTAINABILITY AND EMPIRICAL LITERATURE REVIEW}

Fiscal spending in years of crisis and depression means a counter-cyclical policy. In a neoclassical model, the sustainability of such spending would not be a challenge as it assumes countercyclical behavior in years of economic growth too. Nevertheless, since the 1970s, the European fiscal practice has been rather pro-cyclical with temporary adjustments; many national public budgets in Europe already had high indebtedness in the eve of the crisis in 2008. The concept of fiscal sustainability means that sovereigns' solvency is ensured if current debt equals the net present value of the sum of future primary surpluses (Benczes \& Kutasi, 2010: 67). Otherwise, continuous annual deficits will enforce adjustment to the structure of the public budget.

Namely, the basic form of fiscal sustainability is a net present value of revenues, expenditures, and the existing debt. However, these budget items are affected by economic factors that are (partially or completely) out of control of the fiscal policy.

This way, we get the budget constraint, which is dependent on the interest rate, growth rate, and past deficits.

$\left(g_{t}-\tau_{t}\right)+\left[\left(1+r_{t}\right) /\left(1+n_{t}\right)\right] b_{t-1}=b_{t}$

where $g$ is the government expenditure in ratio to GDP, $\tau$ is the tax revenue in ratio to GDP, $r$ is the real interest rate, $n$ is the growth ratio of GDP, $b$ is the debt ratio to the GDP. 
Thus, according to Fatás et al. (2003), the change of debt is

$\Delta b=g-\tau-+(r-n) b$.

De Grauwe (2000: 167) extended this budget constraint by distinguishing seignorage revenues (m) as follows:

$\Delta b=g-\tau+(r-n) b-m$

From equations ( 1 ), ( 2 ) and ( 3 ), it can be established that the public debt ratio can increase if $r$ exceeds $n$, and/or if the fiscal balance is in deficit $(g-\tau>0)$, and/or if seignorage income is decreasing. Equation (2) makes it obvious that there are factors that cannot really be modified by the fiscal policy in the short term: real interest rate, growth of GDP, inherited public debt from past. Quick adjustments can only be implemented through tax revenues and expenditures.

Of course, there are cyclical phenomena in the budget that must be taken into account in order to understand fiscal solvency. This is why, according to Chalk and Hemming (2000) and Buiter and Grafe (2002), the determination of fiscal sustainability can be refined based on the following criterion: the present value of the initial net public debt and the present value of future deficits altogether should not exceed the present value of the sum of future fiscal surpluses. McCallum (1984) considered it a vulnerable fiscal stance when the accumulation of absolute debt value is faster than the increase rate in interest rate, but slower than the speed of economic growth. Seemingly, it means decreasing debt-to-GDP ratio, but the sustainability criterion is violated.

The budget constraint was refined by the fiscal crowding-out effect (Tobin \& Buiter, 1976) and by the overlapping generations model (Zee, 1988). The approach extended with the crowdingout impact includes the effect of public debt on the stock of capital assets. It is calculated that the effect of taxation on the income remains disposable for the private sector and the effect of public debt on capital markets, market rates, and saving propensity. The microeconomic approach of overlapping generations involves the dynamics originated in the finite horizon of individuals standing behind public bond acquisitions. Moreover, an individual has variable saving preferences and opportunities during his/her own life, which strongly correlates with variable incomes at different ages. This way, the budget constraint can be derived from the individuals' income optimization, namely from their saving propensity, the interest rate elasticity of private investments and savings, and the capital elasticity of the production output. Thus, besides the factors mentioned in equations (1)-(3), higher capital-to-GDP ratio and bigger interest rate elasticity result in an extended budget constraint and improved fiscal sustainability.

Calculating fiscal sustainability is a simple technical, mathematical exercise, but keeping the budget constraint is a political game both in an inter-temporal and in an international sense. The former depends on the current preference of society (or politicians) regarding whether to finance current expenditures or pass them on to future generations by indebting them. The latter is possible because of the globally interconnected community of states, which includes disciplined countries and governments that have net savings.

A budget-constraint-based opportunity to measure long-term budget solvency is a sustainability indicator proposed by Buiter (1985), which determines the difference between current budget deficit and permanent deficit. The latter is derived from the net size of the public sector related to GDP. Blanchard's indicators used in this study are based on a very similar approach.

An alternative index for fiscal sustainability, created by Croce and Juan-Ramon (2003), is the Index of Fiscal Sustainability (IFS):

$I F S_{t}=(\beta-\lambda)=\frac{1-r_{t}}{1+n_{t}^{\text {real }}}-\frac{p s_{t}-p s^{*}}{b_{t-1}-b^{* j}}$

where $p s_{t}$ is the current primary surplus, $p s^{*}$ is the targeted value of the primary balance, $b_{t-1}$ is the rate of inherited public debt, $b$ * is the targeted ratio of public debt, $r_{t}$ is the real interest rate, and $n_{t}^{\text {real }}$ is 
the growth rate of real GDP. This index is not used this time. If the absolute value of IFS is lower than 1 , the public debt is sustainable. According to the budget constraint,

$$
\begin{aligned}
& \text { bt } \leq\left[\frac{\left(1+r_{t}\right)}{\left(1+n_{t}\right)}\right]^{-1} \times p s_{t+1}+\ldots+\left[\frac{\left(1+r_{t}\right)}{\left(1+n_{t}\right)}\right]^{-n} \\
& \times p s_{t+m^{j}} \quad m \rightarrow \infty
\end{aligned}
$$

There are several studies about the fiscal sustainability of European countries, which were written before the global financial and European debt crisis; similarly, there are numerous works that include data from the crisis years. For example, Afonso (2000) or Afonso and Rault (2010) performed stationarity tests for the stock of public debt and cointegration tests between public expenditures and public revenues for the euro countries, and they found that most of the (fifteen) eurozone countries had unsustainable debt according to data before 2007. However, they state that the overall European fiscal stance was sustainable, even though there were many challenges at the national level, which is also consistent with Claeys' results (2007) from his test based on the cointegration relation between government revenues, expenditures, and interest payments based on data before 2002. Nevertheless, the repeated analysis by Afonso and Rault (2015), including data from the crisis years, does not confirm anymore the overall sustainability of EU fiscal policies, but they evidence the emergence of unsustainability.

There are future-oriented studies too. For example, Cournède and Gonand (2008) recommended and assessed scenarios regarding how to restore sustainability. Similarly, Checherita-Westphal et al. (2012) calculated the optimal debt target for long-term solvency. Balassone et al. (2008) focused on the long-term challenge of aging population for the public revenue and expenditure in the EU, and forecasted very long-term future trends in fiscal sustainability. This approach of analysis was repeated in the European Commission (2012), already including information from the crisis years.
Borgy at al. (2011) analyzed the risk premium in relevance to fiscal sustainability. They established that before the crisis year of 2009, there was a strong comovement among the risk premia of the eurozone countries. However, they also refer to Laubach (2011) who found that comovement among yield spreads has weakened since 2009. Namely, the impact of the euro debt crisis caused not only deterioration, but divergence in fiscal sustainability among the members, which is a phenomenon that supports fiscal union. They concluded that, because of the debt crisis, an explosion in the EMU governments' bond yield spreads became a threat to national solvency and to financial stability in Europe. They also found evidence that sharp increase in government debt explains the bulk of the increase in spreads, which limits fiscal stabilization opportunities. But, more importantly, " $[t]$ he increase in spreads was to a large extent driven by increases in risk premia, implying that the deterioration of the economic and fiscal outlook during the crisis led to an endogenous increase in the market price of risk, thereby magnifying the effects on yield spreads much beyond pure compensation for perceived higher default risk" (Borgy et al., 2011: 26).

Beritella and Zhang (2015) analyzed public debt sustainability in the EU using a dynamic, computable general equilibrium model to identify the short-term risk to economy due to fiscal unsustainability, and to prove convergence toward the public debt threshold. They calculated the shortterm fiscal risk in the well-known PIIGS group of countries; their long-term forecast, however, shows no long-term risks, but rather the consolidation of public debt because of trends in GDP and taxation. Neaime (2015) analyzed the long-run, historical sustainability of public finances in some EU countries using the cointegration test on their present value constraint. He concluded that the German and French public budgets have always been sustainable, but the Irish, Italian, Spanish and Portuguese public finances have drifted apart from fiscal sustainability since the 1990s. Chen (2014) examined the sustainability of G-7 and PIIGS countries regarding 
whether they can be characterized by a unit root process with non-linear trend and asymmetric adjustment. The four different autoregressive tests concluded that most of the G-7 and PIIGS countries are "characterized by a unit root process which is in violation of fiscal sustainability."

\section{METHODOLOGY AND DATA}

Sustainability simply means whether a given process, activity or policy could be maintained either in a definite or in an indefinite future. When something is rated as unsustainable, it implies an expectation that certain phenomena might halt or altogether extinguish mechanisms that have been working fine so far. Translated into budget policy, this means that if the (primary) budget balance records constant deficit, it will increase the portfolio of public debt. And due to an increasing debt ratio, government bonds representing this debt will become riskier in terms of redemption and interest payment. Therefore, the sustainability of budget policy is primarily subject to real interest rates and economic growth. Fiscal sustainability can be measured with the indicators proposed by Blanchard (1990), namely the primary gap indicator and the tax gap indicator. ${ }^{2}$ These indicators were used in this research to measure the fiscal sustainability of EU8 +2 countries before the global crisis.

The Blanchard indicators are composed as follows. The primary gap indicator is rooted in the sustainability indicator suggested by Buiter (1985), which was deducted as the difference of permanent (structural) deficit $(d)$ and the current primary deficit $(d t)$, and scaled to the net size of public finances to GDP - the primary gap indicator replaced the size of public finances to public debt.

The permanent deficit term proposed by Blanchard (1990) is

$\hat{d}=\left(n_{t}-r_{t}\right) * b_{t}$,

and the difference is the primary gap, namely

$\hat{d}-d_{t}=\left(n_{t}-r_{t}\right) * b_{t}-d_{t}$,

2 Blanchard has a third indicator too, the so-called long-term tax gap (or tax rate stabilizing debt). where $\hat{d}$ is the permanent deficit and $d_{t}$ is the current deficit. If current deficit exceeds permanent deficit $\left(\hat{d}<d_{t}\right)$, the public budget is not sustainable, and the level of current deficit destabilizes fiscal policy.

Similarly, the tax gap indicator assesses the difference between the current $\operatorname{tax}\left(/{ }_{t}\right)$ rate and the permanent tax rate $\left(\tau^{\prime}\right)$. The permanent tax rate is $\hat{\tau}=g_{t}-\left(n_{t}-r_{t}\right) * b_{t}$,

and the difference is the tax gap, namely

$\tau_{t}-\hat{\tau}=\tau_{t}+\left(n_{t}-r_{t}\right) * b_{t}-g_{t}$.

If $\left(\tau_{t}-\tau^{\imath}\right)$ difference is less than zero, the current tax revenues are not sufficient to secure long-term solvency. Regarding the tax gap, to simplify calculation, overall government revenues are taken into account, since in case of sustainability, the origin of revenue is a secondary question.

As fiscal union is also a risk pool-which is a characteristic that can be considered a commonpool resource of long-term solvency-, overall solvency and willingness to participate are important factors to consider. This is why we analyze country risk premiums to see whether each one of the countries would be a stabilizer or a free rider of the fiscal union.

The source of data is Eurostat, AMECO, and, indirectly, Datastream: GDP-ratio to general government debt, revenues, and expenditures. In case of the real interest rate, it was necessary to calculate it as a difference of nominal interest rate and inflation. In the mentioned databases, 3-months market rates were available historically for every current eurozone country, which is why this is the base for interest rate calculation. Inflation is the annual average change of consumer prices. Current primary balance is calculated as a difference of net lending/borrowing and the interest payable.

In case of real interest rate calculation, it is the difference of nominal interest rate and inflation $(r=i-H I C P)$. In case of the empirical data, there were some dilemmas and constraints of statistics. First of all, as gap indicators deal with the sustainability of public finances, longterm government bond yields were taken into account as nominal interest rates on borrowing. 
This is known as Maastricht criterion interest rates. ${ }^{3}$ Where the Eurostat database was incomplete, the following supplements were made in the database. There are no Estonian sovereign debt securities that comply with the definition of long-term interest rates for convergence purposes. No suitable proxy indicator has been identified. 3-months market rates were taken into account, because Eurostat only published historical data regarding this rate in case of the eurozone countries. For Cyprus, primary market yields are reported. The same applies to Bulgaria and Romania up to December 2005, Slovenia up to October 2003, and Lithuania up to October 2007. A harmonized long-term interest rate is presented starting mid-May 2010. Before, the Luxembourg Government did not have outstanding long-term debt securities with a residual maturity of close to ten years. Therefore, the yield on long-term bond(s) issued by a private credit institution with a residual maturity close to 10 years is presented for the period up to mid-May 2010 and is thus not fully harmonized for that period. In the following cases, the missing data was substituted with 3 and 12-months yields: Bulgaria 1999-2002, Malta, Poland, Slovakia, Latvia and Lithuania 1999-2000, Romania 1999-2005, Slovenia 1999-2001. There were no data for Croatia 1999-2000.

\section{ANALYSIS OF EU FISCAL INDICATORS}

The 28 member states of the EU are analyzed from the perspective of fiscal sustainability. As fiscal union would be built on a monetary integration, sustainability indicators are analyzed since the implementation of the single currency (1999), which was a strong commitment for EU-15 to seek fiscal convergence. According to the primary balance data (Table 1), calculated from net lending/ borrowing reduced with the interest payable, it can be established that the initial commitment to fiscal balance in the eve of the euro disappeared particularly due to the pro-cyclical policy making of

3 http://ec.europa.eu/eurostat/cache/metadata/en/irt_It_ mcby_esms.htm some undisciplined governments before the global recession (2009), and also because of broadly-used, massive, anti-cyclical stimuli during the economic crisis, even in many deeply indebted countries, alongside with sharply increasing risk premium. A serious accumulation of fiscal reserves is only observable in the case of Italy among the indebted eurozone countries. Spain, Greece, Portugal and France, or Ireland did not excel in primary surplus. In any case, only those countries created primary surplus in the EU that earlier reformed their own public finances for sustainability: Germany, Sweden, Denmark, Belgium, Austria, Luxemburg, and the Baltic countries.

However, if we take into account every aspects of long-term solvency, the primary gap data (Table 2) strengthen the conclusion drawn from the primary balance data, with the addition of the UK and Czech Republic to the list. The tax gap data (Table 3), however, do not confirm the restoration of fiscal sustainability after the stimulus period in 2011-2014, except in the case of Germany, Luxembourg and the UK. Namely, there is a serious challenge in the revenue side.

As it was mentioned, fiscal union is a risk community. In the case of the EU, the cyclical movement of the economy in time increases the difference of sovereign fiscal risks among the member countries (see standard deviation in Table 4 and Table 5). That is to say, it is very difficult to create fiscal solidarity between disciplined and free rider players of the European monetary community.

\section{CONCLUSIONS}

This study analyzed the fiscal sustainability of the EU member states, as well as the risk community of a potential European fiscal union. The theory of fiscal sustainability was summarized and explained to a better understanding, and, moreover, sustainability indicators were derived from the terms of budget constraint. It was established that government solvency is determined by economic growth and market rate levels, in addition to internal fiscal factors like inherited debt and the balance of 
revenues and expenditures. The empirical literature review presented the results of existing sustainability analysis regarding the EU. The review strengthened the assumption about the negative impact of the crisis and its anticipation of the vulnerability and room for maneuver of public finances, as well as about fiscal divergence in risk and sustainability indicators among the EU members.

The empirical analysis used the primary gap and the tax gap indicators of fiscal sustainability and the sovereign risk rating of the eurozone and other EU-28 countries. The following conclusions were established: 1 ) the enthusiasm in the majority of eurozone countries for debt sustainability lasted mostly until their accession to the single currency zone. 2) During the economic growth period of 2000s, many of the EU countries had a pro-cyclical fiscal policy according to their primary deficit, which deteriorated their sustainability indicators too. 3) During the period of 2012-2014, only a few EU countries managed to restore debt sustainability according to the primary gap indicator. 4) Although the single currency zone seemed to be an integrating community with declining and converging risk premium in the government bond market, the global financial crisis of 2008-2009 highlighted that the convergence of risk premia happened particularly because of the interim excess liquidity of global financial markets and because rating agencies misrated the risk of sovereign debtors.

Regarding the fiscal union, in the 2010s, the fiscal sustainability structure of the countries shows different engagement or capability to create a risk pool of fiscal federalism either in the eurozone or in the whole EU. The divergence of debt sustainability in the eurozone countries and in the EU means a potential moral hazard in case of a possible fiscal union in a macroeconomic sense. This conclusion does not exclude the feasibility of fiscal federalism in the EU, but, if it happens, it will be driven by political will and intent, which overwrites economic rationale.

\section{REFERENCES}

1. Afonso, A., \& Rault, C. (2010). What do we really know about fiscal sustainability in the EU? A panel data diagnostic. Review of World Economics, 145(4), 731-755.

2. Afonso, A., \& Rault, C. (2015). Multi-step analysis of public finances sustainability. Economic Modelling, 48(8), 199-209.

3. Afonso, A. (2000). Fiscal Policy Sustainability: Some Unpleasant European Evidence (August 2000). ISEG Working Paper, No. 12/2000/DE/CISEP.

4. $\quad$ Balassone, F., Cunha, J., Langenus, G., Manzke, B., Pavot, J., Prammer, D., \& Tommasino P. (2008). Fiscal sustainability and policy implications for the euro area. Banque de France NER, 225.

5. Barnhill, T. M., \& Kopits, G. (2003). Assessing fiscal sustainability under uncertainty. IMF Working Papers, 79.

6. Barro, R. J. (2008). Macroeconomics: A modern approach. Thomson South-Western.

7. Benczes, I. (2014) Intergovernmentalism versus Supranationalism. Challenges and Controversies in European Economic Governance. In I. Benczes (Ed.), Crisis in the West and the East. Economic Governance in Times of Challenge (pp. 59-73). Wien: Wiener Verlag.

8. Benczes, I., \& Kutasi G. (2010). Költségvetési pénzügyek. Hiány, államadósság és fenntarthatóság. Budapest: Akadémiai kiadó (Public finances: Deficit, public debt and sustainability).

9. Beritella, M., \& Zhang, J. (2015). Fiscal sustainability in the EU: From the short-term riskto the long-term challenge. Journal of Policy Modeling, 37(2), 261-280. 
10. Blanchard, O. J. (1990). Suggestions for a New Set of Fiscal Indicators. OECD Working Papers, 79.

11. Borgy, V., Laubach, T., Mésonnier, J-S., \& Renne, J-P. (2011). Fiscal Sustainability, Default Risk and Euro Area Sovereign Bond Spreads. Banque de France Document de Travail, 315.

12. Buiter, W. H. (1985). Guide to public sector debt and deficits. Economic Policy, 1(3), 13-79.

13. Buiter, W. H., \& Grafe, C. (2002). Patching up the Pact: Some Suggestions for Enhancing Fiscal Sustainability on Enlarged European Union. CEPR Discussion Paper, 3496.

14. Chalk, N., \& Hemming, R. (2000). Assessing Fiscal Sustainability in Theory and Practice. IMF Working Papers, WP/00/81.

15. Checherita-Westphal, C., Hughes Hallett, A., \& Rother, P. (2014). Fiscal sustainability using growth-maximising debt targets. Applied Economics, 46(6), 638-647.

16. Chen, S-W. (2014). Testing for Fiscal Sustainability: New evidence from the G-7 and Some European countries. Economic Modelling, 37(1), 1-15.

17. Claeys, P. (2007). Sustainability of EU Fiscal Policies: a Panel Test. Journal of Economic Integration, 22 (1), $112-127$.

18. Cournède, B., \& Gonand, F. (2008). Restoring Fiscal Sustainability in the Euro Area: Raise Taxes or Curb Spending? OECD Economics Department Working Papers, 520.

19. Croce, E., \& Juan-Ramon, V. H. (2003). Assessing fiscal sustainability: A cross-country comparison. IMF Working Papers, WP/03/145.

20. De Grauwe, P. (2000). Economics of monetary union. Oxford: Oxford University Press.

21. Delors Report. (1989). Report on Economic and Monetary Union in the European community. Committee for the Study of Economic and Monetary Union.

22. European Commission. (2012). Fiscal Sustainability Report 2012. European Commission.

23. Fatás, A., von Hagen, J., Hughes-Hallett, A., Strauch, R. R., \& Sibert, A. (2003). Stability and Growth in Europe: Towards a Better Pact. CEPR, ZEI.

24. Fuest, C., \& Peichel, A. (2012). European fiscal union. What is it? Does it work? And are there really no alternatives? IZA Policy Paper, 39.

25. Heinz, F. F., \& Sun, Y. (2014). Sovereign CDS Spreads in Europe-The Role of Global Risk Aversion, Economic Fundamentals, Liquidity, and Spillovers. IMF Working Papers, WP/14/17.

26. Laubach, T. (2011). Fiscal policy and interest rates: The role of sovereign default risk. In R. Clarida, \& F. Giavazzi (Eds.), NBER International Seminar on Macroeconomics 2010 (pp. 7-29). Chicago: The University of Chicago Press.

27. MacDougall Report. (1977). Report of the study group on the role of public finances in the European integration. Vol. 1. Brussels: Commission of the European Communities.

28. Mankiw, N. G. (1997). Macroeconomics. 3rd edition. New York.

29. McCallum, B. T. (1984). Are Bond-Financed Deficits Inflationary? A Ricardian Analysis. Journal of Political Economy, 92(2), 123-135.

30. Neaime, S. (2015). Sustainability of Budget Deficits and Public Debts in Selected Eropean Union Countries. The Journal of Economic Asymmetries, 12(1), 1-21. 
31. Tobin, J., \& Buiter, W. (1976). Long-run effects of fiscal and monetary policy on aggregate demand. In J. L. Stein (Ed.), Monetarism, studies in monetary economics (pp. 273-309). Amsterdam: North-Holland.

32. Trehan, B., \& Walsh, C. E. (1988). Common Trends, The Government's Budget Constraint, and Revenue Smoothing. Journal of Economic Dynamics and Control, 12 (2-3), 425-444.

33. Zee, H. H. (1988). The sustainability and optimality of government debt. IMF Staff Papers, 35 (4), 658-685. 


\section{APPENDIX: TABLES}

Table 1.

\section{Primary balance}

\begin{tabular}{|c|c|c|c|c|c|c|c|c|c|c|c|c|c|c|c|c|}
\hline & 999 & 000 & 2001 & 2002 & 2003 & 2004 & 2005 & 2006 & 2007 & 2008 & 2009 & 2010 & 2011 & 2012 & 2013 & 2014 \\
\hline AT & 8 & 1.6 & 0 & 2.2 & 1 & .8 & 0.7 & 6 & 1.8 & 1.6 & 1 & 5 & 0.2 & 5 & 3 & .2 \\
\hline $\mathrm{BE}$ & 3 & 6 & 7 & 8 & 3.6 & 1.6 & 8 & 4.4 & H. 1 & 2.9 & 1.6 & -0.4 & 0.5 & 0.5 & 4 & .0 \\
\hline BG & 3.7 & 3.6 & 5.3 & 1.0 & 1.8 & 3.6 & 2.6 & 3.1 & 2.2 & 2.4 & -3.4 & -2.5 & -1.3 & 0.2 & -0.1 & -4.9 \\
\hline $\mathrm{HR}^{*}$ & -6.4 & -3.8 & -0.3 & -1.8 & -2.8 & -3.1 & -1.8 & -1.4 & -0.6 & -0.8 & -3.5 & -3.4 & -4.8 & -1.9 & -1.9 & -2.1 \\
\hline CY & -1.2 & 0.9 & 1.0 & -1.2 & -2.7 & -0.7 & 1.0 & 2.0 & 6.0 & 3.5 & -3.1 & -2.7 & -3.5 & -2.9 & -1.8 & -6.0 \\
\hline $\mathrm{CZ}$ & -2.5 & -2.7 & -4.4 & -5.2 & -5.4 & -1.6 & -2.0 & -1.3 & 0.4 & -1.1 & -4.3 & -3.1 & -1.4 & -2.6 & .0 & -0.6 \\
\hline DK & 0 & 5.6 & 4.5 & 3.1 & 2.7 & 4.6 & 7.1 & 6.8 & 6.6 & 4.6 & -0.9 & -0.8 & -0.1 & 1.8 & 0.4 & 3.0 \\
\hline $\mathrm{EE}$ & -2.9 & 0.2 & 0.4 & 0.7 & 2.0 & 2.6 & 1.3 & 3.1 & 2.9 & -2.5 & -2.0 & 0.3 & 1.3 & -0.2 & 0.0 & 0.8 \\
\hline FI & 4.6 & 9.6 & 7.6 & 6.1 & 4.2 & 3.9 & 4.2 & 5.4 & 6.5 & 5.6 & -1.2 & -1.3 & 0.4 & -0.7 & -1.2 & -2.1 \\
\hline FR & 1.3 & 1.5 & 1.5 & -0.2 & -1.2 & -0.8 & -0.6 & 0.2 & 0.1 & -0.4 & -4.8 & -4.4 & -2.5 & -2.2 & -1.8 & -1.7 \\
\hline $\mathrm{DE}$ & 1.3 & 4.0 & -0.1 & -1.0 & -1.3 & -0.9 & -0.7 & 1.0 & 2.9 & 2.5 & -0.6 & -1.7 & 1.5 & 2.2 & 1.9 & 2.1 \\
\hline EL** & 4.2 & 3.5 & 1.9 & 0.7 & -0.7 & -2.5 & -0.9 & -1.5 & -2.2 & -5.4 & -10.2 & -5.3 & -2.9 & -3.7 & -8.4 & 0.3 \\
\hline $\mathrm{HU}$ & 1.6 & 2.3 & 0.6 & -4.9 & -3.1 & -2.1 & -3.7 & -5.4 & -1.0 & 0.5 & -0.1 & -0.4 & -1.3 & 2.3 & 2.0 & 1.5 \\
\hline IR & 4 & 6.8 & 2.4 & 1 & 1 & 2.5 & 2 & 3 & 1.3 & 7 & 8 & 29.3 & 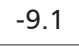 & 9 & -1.4 & 0.1 \\
\hline IT & 46 & 4.8 & 27 & 24 & 1.6 & 0 & 0.3 & 0 & 3.3 & 2.2 & -0.9 & 0.1 & 12 & 2 & 9 & 1.6 \\
\hline LV & -3.1 & -1.8 & -1.1 & -1.5 & -0.9 & -0.3 & 0.1 & -0.2 & -0.3 & -3.5 & -7.6 & -6.8 & -1.6 & 0.8 & 0.6 & -0.1 \\
\hline LT & -1.3 & -1.5 & -2.0 & -0.6 & -0.1 & -0.5 & 0.5 & 0.4 & -0.1 & -2.4 & -7.9 & -5.1 & -7.1 & -1.1 & -0.8 & 0.9 \\
\hline LU & 4.0 & 6.1 & 6.3 & 2.6 & 0.8 & -0.9 & 0.4 & 1.6 & 4.5 & 3.6 & -0.1 & -0.1 & 1.0 & 0.7 & 1.1 & 1.8 \\
\hline MT & -2.9 & 4 & . & -1.5 & - & - & 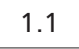 & 1.1 & 1.2 & -0 & 0.0 & . & 0.0 & 0.6 & 0.5 & 0.8 \\
\hline NL & 4.2 & 5.2 & 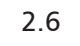 & 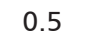 & -0.6 & 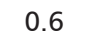 & 1.0 & 2.2 & 2.2 & 2 & -3.4 & -3.2 & 2.5 & 2.5 & 0.5 & -1.0 \\
\hline PL & 07 & 0.0 & -1.7 & -1.9 & -3.1 & -2.5 & -1.5 & -1.2 & 0.3 & -1.5 & -4.8 & -5.0 & -2.4 & -1.0 & -1.5 & -1.4 \\
\hline PT & -0.1 & -0.2 & -1.8 & -0.5 & -1.7 & -3.6 & -3.6 & -1.5 & -0.1 & -0.7 & -6.8 & -8.3 & -3.1 & -0.8 & 0.1 & -2.3 \\
\hline RO & 0.6 & -0.8 & -0.1 & 0.5 & 0.1 & 0.2 & 0.0 & -1.4 & -2.2 & -4.9 & -7.6 & -5.4 & -3.8 & -1.4 & -0.5 & 0.3 \\
\hline SK & -4.0 & -8.0 & -2.5 & -4.6 & -0.2 & -0.2 & -1.2 & -2.2 & -0.5 & -1.1 & -6.5 & -6.2 & -2.6 & -2.4 & -0.7 & -0.9 \\
\hline SI & -0.7 & 1.2 & -1.0 & 0.5 & -0.1 & 0.0 & 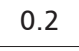 & 0 & . & 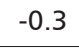 & 4.0 & 4.0 & 4.1 & 2.1 & -12.4 & -1.8 \\
\hline ES & 2.1 & 2.2 & 2.5 & 2 & 1.9 & 2.0 & 2.9 & 3 & 3.6 & -2.9 & -9.3 & -7.5 & -7.0 & -7 & -3.5 & -2.5 \\
\hline SE & 4.6 & 6.5 & 4.0 & 1.4 & 0.8 & 0 & 3 & 3 & 5.0 & 3.6 & 0.5 & 1.1 & 1.0 & 0.0 & -0.6 & -1.0 \\
\hline UK & 3.5 & 3.8 & 2.6 & -0.2 & -1.5 & -1.7 & -1.5 & -0.9 & -0.8 & -2.9 & -8.9 & -6.8 & -4.5 & -5.4 & -2.8 & -3.0 \\
\hline EA19 & $\mathrm{n} / \mathrm{a}$ & $\mathrm{n} / \mathrm{a}$ & $\mathrm{n} / \mathrm{a}$ & $\mathrm{n} / \mathrm{a}$ & $\mathrm{n} / \mathrm{a}$ & $\mathrm{n} / \mathrm{a}$ & & 1.3 & & & -3.5 & -3.5 & -1.2 & -0.7 & -0.2 & 0.1 \\
\hline EU28 & $\mathrm{n} / \mathrm{a}$ & $\mathrm{n} / \mathrm{a}$ & $\mathrm{n} / \mathrm{a}$ & $\mathrm{n} / \mathrm{a}$ & & $\mathrm{n} / \mathrm{a}$ & & 1.0 & 1.1 & 0.2 & -4.1 & -3.7 & -1.6 & -1.4 & -0.6 & -0.5 \\
\hline Mean & 1.2 & 1.9 & 1.3 & 0.2 & 0.5 & 0.1 & 0.0 & 1.0 & 1.7 & -0.1 & -4.2 & -4.1 & -2.1 & -1.3 & -1.1 & -0.7 \\
\hline S.D. & 3.59 & 3.47 & 2.90 & .55 & 2.37 & 2.31 & 2.49 & 2.60 & 2.93 & 3.87 & 4.63 & 4.49 & 2.51 & 2.62 & 2.56 & 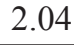 \\
\hline
\end{tabular}

Source: Eurostat, HR '99-`00 \& EL ‘99-‘05 IMF World Economic Outlook; mean = EU-28 average, S.D. = EU28 standard deviation. 
Table 2.

Primary gap, if we demand $d=0, g a p=(n t-r t) * b t$

\begin{tabular}{|c|c|c|c|c|c|c|c|c|c|c|c|c|c|c|c|c|}
\hline & 1999 & 2000 & 2001 & 2002 & 2003 & 2004 & 2005 & 2006 & 2007 & 2008 & 2009 & 2010 & 2011 & 2012 & 2013 & 2014 \\
\hline AT & -39 & -11 & -92 & -103 & -134 & 37 & 55 & 87 & 97 & 23 & -585 & 30 & 253 & 84 & 32 & 35 \\
\hline $\mathrm{BE}$ & -6 & 77 & -208 & -167 & -190 & 130 & 111 & 90 & 76 & 72 & -615 & 153 & 99 & -21 & -126 & 10 \\
\hline BG & -698 & 748 & 419 & 284 & 41 & 265 & 253 & 213 & 179 & 163 & -127 & -46 & -6 & -34 & -32 & -95 \\
\hline $\mathrm{HR}$ & $\mathrm{n} / \mathrm{a}$ & $\mathrm{n} / \mathrm{a}$ & 53 & 183 & 172 & -44 & 40 & 141 & 110 & 72 & -625 & -393 & -296 & -341 & -264 & -361 \\
\hline$C Y$ & -25 & 230 & -115 & 18 & 131 & 45 & 47 & 152 & 142 & 159 & -346 & -34 & -125 & -501 & -1226 & -946 \\
\hline$C Z$ & -55 & 48 & 29 & -49 & -17 & 76 & 125 & 145 & 117 & 125 & -308 & -15 & 16 & -8 & -54 & 35 \\
\hline DK & 5 & 40 & -96 & -106 & -88 & -35 & 26 & 60 & -49 & -46 & -307 & 37 & 54 & 14 & -79 & 4 \\
\hline $\mathrm{EE}$ & -33 & 45 & 32 & 33 & 33 & 35 & 50 & 51 & 35 & -7 & -143 & 24 & 68 & 86 & 46 & 34 \\
\hline $\mathrm{FI}$ & 43 & 128 & 11 & -51 & -36 & -5 & 10 & 62 & 85 & 10 & -435 & 80 & 140 & -5 & -42 & -39 \\
\hline FR & -37 & 18 & -66 & -112 & -73 & 66 & 6 & 32 & -19 & -57 & -510 & 47 & 92 & -13 & -46 & -83 \\
\hline $\mathrm{DE}$ & -114 & -51 & -69 & -201 & -238 & -67 & -50 & 116 & 88 & -5 & -626 & 206 & 280 & 79 & 25 & 93 \\
\hline EL & -97 & 99 & 220 & 263 & 464 & 364 & 50 & 560 & 203 & -107 & -1115 & -1551 & -3978 & -4703 & -2565 & -1402 \\
\hline $\mathrm{HU}$ & -38 & 155 & 257 & 144 & 97 & 206 & 79 & 44 & 103 & -104 & -917 & -152 & -157 & -305 & -179 & -85 \\
\hline IR & 401 & 363 & 160 & 172 & 110 & 74 & 135 & 125 & 98 & -155 & -781 & -607 & -645 & -495 & -233 & 343 \\
\hline IT & -157 & 76 & -114 & -217 & -126 & -36 & -47 & 15 & -99 & -223 & -1014 & -85 & -223 & -614 & -607 & -408 \\
\hline LV & -46 & 32 & 20 & 49 & 89 & 137 & 161 & 142 & 124 & 98 & -850 & -718 & 192 & 71 & -13 & 24 \\
\hline LT & -161 & -46 & -1 & 14 & 57 & 62 & 118 & 122 & 196 & 118 & -713 & -100 & 184 & 86 & 34 & 17 \\
\hline LU & 32 & 41 & -2 & 7 & 4 & 31 & 29 & 34 & 48 & -19 & -149 & 104 & 65 & 6 & 100 & 82 \\
\hline MT & $\mathrm{n} / \mathrm{a}$ & $\mathrm{n} / \mathrm{a}$ & -202 & -14 & -44 & -114 & 122 & 5 & -1 & 200 & -355 & 89 & 8 & 106 & 17 & 115 \\
\hline $\mathrm{NL}$ & 144 & 56 & 109 & -43 & -80 & -35 & 16 & 64 & 43 & -18 & -367 & -41 & 74 & -15 & 10 & -10 \\
\hline PL & -114 & -149 & -156 & -145 & -69 & 82 & 22 & 107 & 191 & 95 & 24 & 33 & 161 & 16 & -108 & -6 \\
\hline PT & 67 & 51 & 61 & -29 & -104 & 10 & -36 & 48 & 33 & -116 & -678 & -202 & -938 & -1478 & -907 & -397 \\
\hline RO & -473 & -41 & -55 & 2 & 97 & 58 & 84 & 92 & 59 & 115 & -260 & -61 & -13 & -100 & 49 & -12 \\
\hline SK & -258 & 240 & 119 & 45 & 366 & 315 & 192 & 258 & 245 & 138 & -335 & 79 & 106 & 34 & -16 & 18 \\
\hline SI & 65 & 56 & 16 & 70 & 56 & 92 & 71 & 113 & 140 & 91 & -389 & -20 & -106 & -307 & -352 & 11 \\
\hline ES & 120 & 190 & 91 & 79 & 104 & 100 & 157 & 156 & 81 & 33 & -410 & -135 & -231 & -511 & -438 & -149 \\
\hline SE & 1 & 32 & -42 & -65 & 3 & 42 & 11 & 108 & 36 & -44 & -264 & 184 & 54 & -36 & -20 & 34 \\
\hline UK & -26 & -29 & -37 & -40 & 4 & -45 & 27 & 27 & -7 & -73 & -353 & 110 & 297 & 194 & 242 & 202 \\
\hline EA19 & $\mathrm{n} / \mathrm{a}$ & $\mathrm{n} / \mathrm{a}$ & $\mathrm{n} / \mathrm{a}$ & $n / a$ & $n / a$ & $\mathrm{n} / \mathrm{a}$ & $n / a$ & $\mathrm{n} / \mathrm{a}$ & $\mathrm{n} / \mathrm{a}$ & $n / a$ & $\mathrm{n} / \mathrm{a}$ & $n / a$ & -3 & -192 & -181 & -68 \\
\hline EU28 & $\mathrm{n} / \mathrm{a}$ & $\mathrm{n} / \mathrm{a}$ & $\mathrm{n} / \mathrm{a}$ & $\mathrm{n} / \mathrm{a}$ & $\mathrm{n} / \mathrm{a}$ & $\mathrm{n} / \mathrm{a}$ & $\mathrm{n} / \mathrm{a}$ & $\mathrm{n} / \mathrm{a}$ & $\mathrm{n} / \mathrm{a}$ & $\mathrm{n} / \mathrm{a}$ & $n / a$ & $\mathrm{n} / \mathrm{a}$ & 43 & -130 & -108 & -18 \\
\hline
\end{tabular}

Source: Author's calculation based on Eurostat and IMF World Economic Outlook data, and Blanchard's index (1990). 
Table 3.

Tax gap, if we demand $T t=g t, g a p=(n t-r t) * b t-g t$

\begin{tabular}{|c|c|c|c|c|c|c|c|c|c|c|c|c|c|c|c|c|}
\hline & 1999 & 2000 & 2001 & 2002 & 2003 & 2004 & 2005 & 2006 & 2007 & 2008 & 2009 & 2010 & 2011 & 2012 & 2013 & 2014 \\
\hline AT & -90 & -61 & -143 & -154 & -185 & -16 & 4 & 37 & 48 & -27 & -639 & -22 & 202 & 33 & -19 & -18 \\
\hline $\mathrm{BE}$ & -55 & 29 & -257 & -216 & -240 & 82 & 60 & 42 & 28 & 23 & -668 & 101 & 46 & -76 & -181 & -45 \\
\hline BG & -737 & 708 & 379 & 245 & 3 & 227 & 216 & 179 & 140 & 125 & -167 & -84 & -40 & -69 & -71 & -134 \\
\hline $\mathrm{HR}$ & $\mathrm{n} / \mathrm{a}$ & $\mathrm{n} / \mathrm{a}$ & 8 & 135 & 125 & -91 & -5 & 95 & 65 & 28 & -673 & -440 & -344 & -388 & -312 & -409 \\
\hline $\mathrm{CY}$ & -59 & 195 & -150 & -19 & 90 & 6 & 7 & 113 & 104 & 120 & -389 & -76 & -168 & -543 & -1268 & -995 \\
\hline$C Z$ & -96 & 8 & -13 & -93 & -66 & 34 & 83 & 104 & 77 & 85 & -352 & -58 & -27 & -52 & -96 & -7 \\
\hline DK & -49 & -13 & -149 & -159 & -142 & -88 & -25 & 10 & -98 & -97 & -363 & -20 & -3 & -45 & -136 & -53 \\
\hline EE & -74 & 9 & -3 & -3 & -2 & 0 & 16 & 17 & 1 & -46 & -189 & -17 & 30 & 46 & 7 & -5 \\
\hline $\mathrm{FI}$ & -8 & 80 & -37 & -100 & -85 & -54 & -39 & 14 & 39 & -38 & -490 & 25 & 86 & -61 & -100 & -97 \\
\hline FR & -89 & -33 & -118 & -164 & -125 & 13 & -47 & -20 & -72 & -110 & -566 & -9 & 36 & -69 & -103 & -140 \\
\hline $\mathrm{DE}$ & -161 & -95 & -116 & -248 & -286 & -114 & -96 & 71 & 45 & -49 & -673 & 159 & 235 & 35 & -19 & 49 \\
\hline EL & -141 & 54 & 176 & 219 & 421 & 321 & 7 & 515 & 156 & -158 & -1169 & -1603 & -4032 & -4757 & -2625 & -1452 \\
\hline $\mathrm{HU}$ & -87 & 108 & 210 & 93 & 48 & 157 & 29 & -8 & 53 & -152 & -967 & -202 & -207 & -354 & -229 & -135 \\
\hline IR & 367 & 332 & 127 & 138 & 77 & 41 & 102 & 91 & 62 & -197 & -828 & -673 & -691 & -538 & -274 & 304 \\
\hline IT & -204 & 30 & -162 & -264 & -173 & -83 & -94 & -32 & -146 & -271 & -1065 & -135 & -273 & -665 & -657 & -459 \\
\hline LV & -87 & -6 & -15 & 14 & 56 & 102 & 126 & 106 & 91 & 61 & -894 & -762 & 153 & 34 & -49 & -13 \\
\hline LT & -201 & -82 & -36 & -20 & 25 & 28 & 84 & 88 & 161 & 80 & -758 & -143 & 141 & 50 & -2 & -18 \\
\hline LU & -8 & 5 & -39 & -34 & -39 & -12 & -14 & -6 & 10 & -58 & -194 & 60 & 22 & -37 & 56 & 38 \\
\hline MT & $\mathrm{n} / \mathrm{a}$ & $n / a$ & -244 & -55 & -89 & -157 & 80 & -37 & -42 & 157 & -397 & 48 & -33 & 63 & -26 & 71 \\
\hline $\mathrm{NL}$ & 101 & 15 & 66 & -87 & -125 & -79 & -26 & 20 & 0 & -62 & -415 & -89 & 27 & -63 & -37 & -57 \\
\hline PL & -158 & -191 & -201 & -190 & -115 & 38 & -22 & 62 & 148 & 50 & -21 & -13 & 117 & -27 & -150 & -48 \\
\hline PT & 25 & 8 & 17 & -72 & -150 & -36 & -83 & 3 & -12 & -161 & -728 & -254 & -988 & -1527 & -957 & -446 \\
\hline RO & -512 & -79 & -91 & -33 & 64 & 25 & 51 & 57 & 21 & 76 & -300 & -101 & -52 & -136 & 14 & -46 \\
\hline SK & -305 & 188 & 75 & 1 & 326 & 278 & 153 & 219 & 209 & 101 & -379 & 37 & 66 & -6 & -57 & -24 \\
\hline SI & 20 & 10 & -31 & 25 & 10 & 46 & 26 & 69 & 98 & 47 & -438 & -69 & -155 & -355 & -412 & -39 \\
\hline ES & 80 & 151 & 53 & 40 & 65 & 61 & 119 & 118 & 42 & -8 & -456 & -181 & -277 & -558 & -483 & -192 \\
\hline SE & -55 & -22 & -95 & -119 & -51 & -11 & -42 & 56 & -14 & -94 & -317 & 132 & 3 & -89 & -73 & -19 \\
\hline UK & -64 & -67 & -76 & -80 & -37 & -88 & -16 & -16 & -50 & -119 & -402 & 61 & 250 & 147 & 196 & 158 \\
\hline EA19 & $n / a$ & $n / a$ & $\mathrm{n} / \mathrm{a}$ & $\mathrm{n} / \mathrm{a}$ & $\mathrm{n} / \mathrm{a}$ & $n / a$ & $\mathrm{n} / \mathrm{a}$ & $\mathrm{n} / \mathrm{a}$ & $\mathrm{n} / \mathrm{a}$ & $n / a$ & $\mathrm{n} / \mathrm{a}$ & $n / a$ & -52 & -242 & -230 & -117 \\
\hline EU28 & $\mathrm{n} / \mathrm{a}$ & $\mathrm{n} / \mathrm{a}$ & $\mathrm{n} / \mathrm{a}$ & $\mathrm{n} / \mathrm{a}$ & $\mathrm{n} / \mathrm{a}$ & $\mathrm{n} / \mathrm{a}$ & $\mathrm{n} / \mathrm{a}$ & $\mathrm{n} / \mathrm{a}$ & $\mathrm{n} / \mathrm{a}$ & $\mathrm{n} / \mathrm{a}$ & $\mathrm{n} / \mathrm{a}$ & $\mathrm{n} / \mathrm{a}$ & -6 & -179 & -156 & -66 \\
\hline
\end{tabular}

Source: Author's calculation based on Eurostat and IMF World Economic Outlook data, and Blanchard's index (1990). 
Table 4.

Long-term government bond rates (Maastricht indicator)

\begin{tabular}{|c|c|c|c|c|c|c|c|c|c|c|c|c|c|c|c|c|}
\hline & 1999 & 2000 & 2001 & 2002 & 2003 & 2004 & 2005 & 2006 & 2007 & 2008 & 2009 & 2010 & 2011 & 2012 & 2013 & 2014 \\
\hline EA & 4.66 & 5.44 & 5.00 & 4.91 & 4.14 & 4.12 & 3.42 & 3.84 & 4.32 & 4.31 & 3.82 & 3.60 & 4.34 & 3.86 & 2.99 & 2.04 \\
\hline $\mathrm{BE}$ & 4.75 & 5.59 & 5.13 & 4.99 & 4.18 & 4.15 & 3.43 & 3.81 & 4.33 & 4.42 & 3.90 & 3.46 & 4.23 & 3.00 & 2.41 & 1.71 \\
\hline BG & : & : & : & : & 6.45 & 5.36 & 3.87 & 4.18 & 4.54 & 5.38 & 7.22 & 6.01 & 5.36 & 4.50 & 3.47 & 3.35 \\
\hline$C Z$ & : & : & 6.31 & 4.88 & 4.12 & 4.82 & 3.54 & 3.80 & 4.30 & 4.63 & 4.84 & 3.88 & 3.71 & 2.78 & 2.11 & 1.58 \\
\hline DK & 4.91 & 5.64 & 5.08 & 5.06 & 4.31 & 4.30 & 3.40 & 3.81 & 4.29 & 4.28 & 3.59 & 2.93 & 2.73 & 1.40 & 1.75 & 1.32 \\
\hline $\mathrm{DE}$ & 4.49 & 5.26 & 4.80 & 4.78 & 4.07 & 4.04 & 3.35 & 3.76 & 4.22 & 3.98 & 3.22 & 2.74 & 2.61 & 1.50 & 1.57 & 1.16 \\
\hline IR & 4.71 & 5.51 & 5.01 & 5.01 & 4.13 & 4.08 & 3.33 & 3.76 & 4.31 & 4.53 & 5.23 & 5.74 & 9.60 & 6.17 & 3.79 & 2.37 \\
\hline EL & 6.30 & 6.10 & 5.30 & 5.12 & 4.27 & 4.26 & 3.59 & 4.07 & 4.50 & 4.80 & 5.17 & 9.09 & 15.75 & 22.50 & 10.05 & 6.93 \\
\hline ES & 4.73 & 5.53 & 5.12 & 4.96 & 4.12 & 4.10 & 3.39 & 3.78 & 4.31 & 4.37 & 3.98 & 4.25 & 5.44 & 5.85 & 4.56 & 2.72 \\
\hline FR & 4.61 & 5.39 & 4.94 & 4.86 & 4.13 & 4.10 & 3.41 & 3.80 & 4.30 & 4.23 & 3.65 & 3.12 & 3.32 & 2.54 & 2.20 & 1.67 \\
\hline HR & : & : & : & : & : & : & : & 4.43 & 4.93 & 6.04 & 7.83 & 6.29 & 6.54 & 6.13 & 4.68 & 4.05 \\
\hline IT & 4.73 & 5.58 & 5.19 & 5.03 & 4.25 & 4.26 & 3.56 & 4.05 & 4.49 & 4.68 & 4.31 & 4.04 & 5.42 & 5.49 & 4.32 & 2.89 \\
\hline$C Z$ & : & : & 7.62 & 5.70 & 4.74 & 5.80 & 5.16 & 4.13 & 4.48 & 4.60 & 4.60 & 4.60 & 5.79 & 7.00 & 6.50 & 6.00 \\
\hline LV & : & : & 7.57 & 5.41 & 4.90 & 4.86 & 3.88 & 4.13 & 5.28 & 6.43 & 12.36 & 10.34 & 5.91 & 4.57 & 3.34 & 2.51 \\
\hline LT & : & : & 8.15 & 6.06 & 5.32 & 4.50 & 3.70 & 4.08 & 4.55 & 5.61 & 14.00 & 5.57 & 5.16 & 4.83 & 3.83 & 2.79 \\
\hline LU & 4.66 & 5.52 & 4.86 & 4.70 & 3.32 & 2.84 & 2.41 & 3.30 & 4.46 & 4.61 & 4.23 & 3.17 & 2.92 & 1.82 & 1.85 & 1.34 \\
\hline $\mathrm{HU}$ & : & : & 7.95 & 7.09 & 6.82 & 8.19 & 6.60 & 7.12 & 6.74 & 8.24 & 9.12 & 7.28 & 7.64 & 7.89 & 5.92 & 4.81 \\
\hline MT & : & : & 6.19 & 5.82 & 5.04 & 4.69 & 4.56 & 4.32 & 4.72 & 4.81 & 4.54 & 4.19 & 4.49 & 4.13 & 3.36 & 2.61 \\
\hline $\mathrm{NL}$ & 4.63 & 5.40 & 4.96 & 4.89 & 4.12 & 4.10 & 3.37 & 3.78 & 4.29 & 4.23 & 3.69 & 2.99 & 2.99 & 1.93 & 1.96 & 1.45 \\
\hline AT & 4.68 & 5.56 & 5.08 & 4.96 & 4.14 & 4.13 & 3.39 & 3.80 & 4.30 & 4.36 & 3.94 & 3.23 & 3.32 & 2.37 & 2.01 & 1.49 \\
\hline PL & : & : & 10.68 & 7.36 & 5.78 & 6.90 & 5.22 & 5.23 & 5.48 & 6.07 & 6.12 & 5.78 & 5.96 & 5.00 & 4.03 & 3.52 \\
\hline PT & 4.78 & 5.59 & 5.16 & 5.01 & 4.18 & 4.14 & 3.44 & 3.91 & 4.42 & 4.52 & 4.21 & 5.40 & 10.24 & 10.55 & 6.29 & 3.75 \\
\hline RO & : & : & : & : & : & : & : & 7.23 & 7.13 & 7.70 & 9.69 & 7.34 & 7.29 & 6.68 & 5.41 & 4.49 \\
\hline SI & : & : & : & 8.72 & 6.40 & 4.68 & 3.81 & 3.85 & 4.53 & 4.61 & 4.38 & 3.83 & 4.97 & 5.81 & 5.81 & 3.27 \\
\hline SK & : & : & 8.04 & 6.94 & 4.99 & 5.03 & 3.52 & 4.41 & 4.49 & 4.72 & 4.71 & 3.87 & 4.45 & 4.55 & 3.19 & 2.07 \\
\hline $\mathrm{FI}$ & 4.72 & 5.48 & 5.04 & 4.98 & 4.13 & 4.11 & 3.35 & 3.78 & 4.29 & 4.29 & 3.74 & 3.01 & 3.01 & 1.89 & 1.86 & 1.45 \\
\hline SE & 4.98 & 5.37 & 5.11 & 5.30 & 4.64 & 4.42 & 3.38 & 3.70 & 4.17 & 3.89 & 3.25 & 2.89 & 2.61 & 1.59 & 2.12 & 1.72 \\
\hline UK & 5.01 & 5.33 & 5.01 & 4.91 & 4.58 & 4.93 & 4.46 & 4.37 & 5.06 & 4.50 & 3.36 & 3.36 & 2.87 & 1.74 & 2.03 & 2.14 \\
\hline Mean & 4.85 & 5.52 & 6.013 & 5.52 & 4.61 & 4.64 & 3.8 & 4.22 & 4.69 & 4.96 & 5.454 & 4.714 & 5.31 & 4.931 & 3.693 & 2.76 \\
\hline S.D. & 0.43 & 0.19 & 1.558 & 1.02 & 0.8 & 1.06 & 0.86 & 0.9 & 0.71 & 1.06 & 2.762 & 1.954 & 2.86 & 4.117 & 1.955 & 1.45 \\
\hline EU28 & : & : & 5.32 & 5.06 & 4.35 & 4.44 & 3.70 & 4.08 & 4.56 & 4.55 & 4.11 & 3.82 & 4.27 & 3.65 & 2.96 & 2.21 \\
\hline
\end{tabular}

Source: Eurostat; S.D. = standard deviation; mean $=$ unweighted average of EU-28 members. 
Table 5.

CDS indicators

\begin{tabular}{|c|c|c|c|c|c|c|c|c|c|c|c|c|c|c|c|c|c|c|c|c|c|}
\hline & AT & BE & BG & HR & CZ & EE & FR & DE & EL & HU & IR & IT & LV & LT & NL & PL & PT & RO & SK & SI & ES \\
\hline 2009, March & 207 & 123 & 589 & 495 & 257 & 649 & 77 & 72 & 219 & 547 & 295 & 171 & 1044 & 767 & 108 & 323 & 116 & 626 & 170 & 164 & 126 \\
\hline 2010, May & 71 & 97 & 242 & 234 & 92 & 113 & 71 & 46 & 683 & 238 & 219 & 170 & 357 & 261 & 46 & 139 & 309 & 256 & 84 & 76 & 203 \\
\hline 2011, July & 78 & 179 & 229 & 301 & 93 & 93 & 102 & 54 & 2314 & 294 & 985 & 265 & 213 & 211 & 48 & 163 & 1045 & 249 & 126 & 116 & 321 \\
\hline 2012, June & 181 & 262 & 346 & 530 & 135 & 117 & 200 & 103 & 10356 & 557 & 663 & 536 & 300 & 282 & 119 & 235 & 1022 & 437 & 255 & 394 & 586 \\
\hline Change & -26 & 139 & -243 & 35 & -122 & -532 & 123 & 31 & 10137 & 10 & 368 & 365 & -744 & -485 & 11 & -88 & 906 & -189 & 85 & 230 & 460 \\
\hline
\end{tabular}

\begin{tabular}{|c|c|c|}
\hline & Mean & S.D. \\
\hline 2009, March & 340.24 & 269.44 \\
\hline 2010, May & 190.81 & 145.54 \\
\hline 2011, July & 356.14 & 521.29 \\
\hline 2012, June & 838.86 & 2192.36 \\
\hline
\end{tabular}

Source: Heinz \& Sun (2014), refer to Datastream; S.D. = standard deviation; mean = average of the countries.

Missing data: CY, DK, SE, MT, LU, FI, UK

Country abbreviations:

$\mathrm{EA}=$ current eurozone, $\mathrm{EA} 19=19$ eurozone members, EU28 $=28 \mathrm{EU}$ members

$\mathrm{AT}=$ Austria, $\mathrm{BE}=$ Belgium, $\mathrm{BG}=$ Bulgaria, $\mathrm{HR}=$ Croatia, $\mathrm{CY}=$ Cyprus, $\mathrm{CZ}=$ Czech Republic, $\mathrm{DK}=$ Denmark, EE = Estonia,

$\mathrm{FI}=$ Finland, FR = France, $\mathrm{DE}=$ Germany, $\mathrm{EL}=$ Greece, $\mathrm{HU}=$ Hungary, IR =Ireland, IT = Italy, LV = Latvia, LT = Lithuania,

$\mathrm{LU}=$ Luxemburg, $\mathrm{MT}=$ Malta, $\mathrm{NL}=$ Netherlands, $\mathrm{PL}=$ Poland, $\mathrm{PT}=$ Portugal, $\mathrm{RO}=$ Romania, $\mathrm{SK}=$ Slovakia, $\mathrm{SI}=\mathrm{Slovenia}$,

$\mathrm{ES}=$ Spain, $\mathrm{SE}=$ Sweden, $\mathrm{UK}=$ United Kingdom 